Ethiopian Journal of Environmental Studies \& Management 10(1): 1 - 10, 2017.

ISSN:1998-0507

doi: http://dx.doi.org/10.4314/ejesm.v10i1.1

Submitted: September 09, 2016

Accepted: January 16, 2017

\title{
EXPLORING REAL ESTATE INVESTMENT TRUST (REIT) AS A HOUSING FINANCE OPTION IN NIGERIA
}

\author{
AFOLAYAN, A.S. \\ Department of Estate Management, Faculty of Environmental Sciences, University of Lagos, \\ Nigeria \\ Email: aafolayan@unilag.edu.ng
}

\begin{abstract}
While traditional housing finance system in Nigeria could not stem the estimated shortage of 17 million, some identified modern sources had also made little impact on housing finance. Sustainable real estate financing requires a system which can be repackaged and traded for further creation of credit over time as fitting into the structure of Real Estate Investment Trust (REIT). The paper examines literature for the nature and workings of REIT. It identifies REIT types and examples as well as its benefits across its operational world. In the applicability of REIT to Nigeria, some germane considerations are explored as related to ownership structure and institutional investors among others. The study finds out that the level of appreciation of REIT is low in Nigeria. The performance of the Stock Exchange (SE) too has not been very encouraging for REITs' operation. For the few REIT companies listed on the SE, the share prices are low partly because of a recent crash of the Nigerian stock market, from which recovery is very slow. While the national housing policy in Nigeria absolves the government from direct construction of houses, private or quasi-public housing development institutions need to find sustainable means of housing finance. This paper contributes to the discussions on alternative means of housing finance as REIT could be subscribed to even by small investors. However, improved education on REIT could also ameliorate housing finance in Nigeria.
\end{abstract}

Key Words: Housing finance, Housing market, REITs, Stock market

\section{Introduction}

Housing delivery is very sensitive to the structure and operations of financing available for it. Amao and Odunjo (2014) acknowledged housing sector as one of the first which would feel the impact of any tight money market, as is in Nigeria today. The housing financing mechanism in Nigeria has two components; the traditional and the modern. The traditional and informal finance system includes the operations of esusu (traditional thrift contribution), traditional cooperatives, cooperation among relatives or age grades as well as individual and family savings. Housing production from these sources is characteristically low, both in quantity and 
quality when compared with modern day requirements.

On the other hand, the evolved modern and formal financing system encompasses the Federal Mortgage Bank of Nigeria $(\mathrm{FMBN})$ as apex authority in the assemblage of Commercial banks, Merchant banks, specialised Development Banks, Pension Fund and Insurance Companies. There are also financing options from the informal sector, corporate bodies and developers or contractors. However, the mortgage arrangement under this complex system remained largely undeveloped over the years. EFInA (Enhancing Financial Innovation and Access) in conjunction with Finmark Trust in 2010, attested to it that the Nigerian Mortgage system generated less than 100,000 transactions between 1960 and 2009, a period of almost 50 years (www.housingfinanceafrica.org). The contribution of this sector to the Nigerian Gross Domestic Product (GDP) was also found to be below 5\% in 2009. This source further reiterated that the mortgage loans and advance within the last five years of this period culminated at $0.5 \%$ of GDP. This trailed much significantly behind those of the US at $77 \%$, the UK at $80 \%$ and even Malaysia at 33\% at that moment.

The mortgage and housing finance market in Nigeria is also bedeviled by bureaucracy and very high interest rates as well as high level inflation (Sanusi, 2003). The World Bank (2008) and Kama et al. (2013) confirmed inflation and general high level of interest rates as two of key macroeconomic variables distorting housing finance in Nigeria. Thus, the Nigeria current estimate of national housing deficit figure of 17 million units appears reasonably inferred from the earlier postulation of 15 million by
Mabogunje (2004) as the mismatch continued to swell.

By its nature, real estate development is capital intensive just as the product enjoys long economic life span. These two, out of the several attributes of real estate investment, make the delivery system particularly susceptible to a specialised form of funding; large quantity, the amortisation of which can be spread over a reasonably long period of time. This calls for availability of a sustainable pool of funds which enjoys long term repayment while new requests continue to be accessed with contribution from many people. One investment strategy which can fit into this requirement, while at the same time reward the investors as an expansion of the traditional cooperative arrangement, is the Real Estate Investment Trust (REIT) vehicle.

Walsmley (2007) recognised REIT as a unit trust invested in real estate. It is a form of property securitisation (Newell and Fife, 1995). REITs can be publicly or privately held. Public REITs, however, are listed on the public stock exchange like shares of common stock in other companies. As some REITs combine capital fund from many small or big investors for their operations, they provide opportunity for a wide range of investors to participate in ownership of ventures spanning a broad spectrum of portfolios (www.reits.com). Known for being relatively liquid and transparent instruments, REITs typically pay regular and predictable dividends to investors and offer high yields of $4 \%-7 \%$. This is attractive compared with equity or fixed-income instruments (www.financeasia.com). REITs are mostly given different country-specific names in different nations. Thus we could talk of JREIT in Japan, LPT in Australia, SIIC in France, and SICAFI in Belgium. The 
origin dates back to the American Congress REIT Act in 1960. By this Act, such business trusts are exempted from federal tax on income shared to stockholders. The REIT philosophy enables retail investors to have small holdings in broad-based and professionally-managed real asset market for a share of profit commensurate with the respective holding power.

REITs come in three types; The Mortgage REITs, Equity REITs and Hybrid REITs. The Mortgage REITs (MREITs) are essentially mortgage lenders usually with at least $75 \%$ of their invested assets in mortgages secured by Real Estate. Equity REITs (EREITs) holds $75 \%$ of its assets in the ownership of commercial, industrial and residential properties. The Hybrid REITs combine both mortgage and equity characters. Traditionally, REITs are not partnerships but, as in the case for other corporations, REITs use partnerships to engage in joint ventures. (www.InvestinREITS.com). REITs can be close- or open-ended. A close-end REIT is that which does not issue more shares after the initial stock offer.

\section{Some International Examples}

Below are analysed examples of REITs in some countries across the world

\section{US REITS}

In the US, to conform to American Internal Revenue Code and qualify as a REIT, the organisation is expected, among other things to:

- be a corporation, business trust, or association

- $\quad$ have a board of directors or trustees

- must have at least 100 shareholders, with not more than $50 \%$ of the shares held by five or fewer persons

- must derive at least $75 \%$ of its gross income from real estate. This would include rents, mortgage interest, gains from selling Real Estate and dividends from investing in other REITs.

- not be involved in short-term property holdings that are sold for quick profits

- $\quad$ share at least $95 \%$ of its annual income to shareholders

The US REIT, additionally, may not hold more than $10 \%$ of the outstanding voting securities of any one issuer. Furthermore, not more than $5 \%$ of its total assets may consist of the securities of any one issuer, unless that issuer is another REIT.

The US REIT was also precluded by tax rules from obtaining more than $30 \%$ of its income from the sum total of securities held for less than one year. This is limitation to restrict REIT's ability to compete with taxable developers and brokers by building/acquiring properties for sale or/and engaging heavily in securities trading (Campbell and Sirmans, 2002).

In addition to these general rules, US REITs are encased in structure, financing and operation to reduce 'unfair' competition with taxable organisations. Most US REITs are public organisations majority of which are listed on the NY Stock Exchange. The most fundamental distinction for US REITs is that between Equity and Mortgage REITs. While Mortgage REITs originate and/or hold mortgages, Equity REITs invest directly in properties. The equity REITs, by early $21^{\text {st }}$ century estimate, outnumber mortgage REITs in the membership of National Association of REITs (NAREIT) in US (Campbell and Sirmans, 2002)

\section{Australian REITs}

Australia REITs were known as Listed Property Trusts (LPTs). This came in two 
forms; the pure real estate portfolio investments and 'staple securities'. The 'staple securities' usually tie up direct property investments with that in a fund manager and/or a property development company

(www.overseaspropertymall.com). This, according to the source, was an attempt to overcome the country's relative shortage of potential real estate investments by diluting the pure real estate LPTs portfolios.

The REITs listed on the exchange were classified as Listed Property Trusts (LPTs) while the private ones were known as Unlisted Property Trusts. However, these have since (March 2008) been collectively renamed Australian REITs (A-REITs) to conform to worldwide identification format.

\section{UK-REITS}

The fear of US REITs' cross-border operations in the ongoing global setting was one of the reasons which geared up the establishment of REITs especially in UK. Hamson (2001) reiterated how UK property company culture came under criticism, among other things, for losing ground to US companies in particular. The introduction of REIT to Europe was also earlier limited to two countries: Belgium and The Netherlands before developments in other parts (Campbell and Sirmans, 2002). A new UK REIT tax regime was introduced by the Finance Act 2006 (Nathanson, 2006). This was the result of twenty years lobbying of the Legislature by the UK real estate industry (kpmg.co.uk/industries/cm). January 1, 2007 marked the formal take-off of REITs in UK. Thus on Tuesday the $2^{\text {nd }}$ day of January, the transformation of existing property Investment Company was championed by nine listed British companies namely Land Securities, British
Land, Hammerson, Liberty International, Brixton, Great Portland Estates, Primary Health Properties, and Workspace \& Slough Estates (www.telegraph.co.uk/money). It was provided that a REIT would distribute at least $90 \%$ of its property rental business profit in each accounting period. Apart from this, there was a provision for entry charge of $2 \%$ of the gross market value of the properties involved in the property rental business at the beginning of the first accounting period for which the company becomes a REIT. Furthermore, while enjoying corporate tax advantage on its ring-fenced assets, a REIT was required to withhold tax at the basic rate of $22 \%$ from distributions to shareholders paid out of profits which have benefited from a tax exemption. According to the KPMG group, a UK REIT may be subjected to tax charges without the loss of REIT status, if it breaches an interest cover test (a limit on the ratio of profits to interest of 1.25) or has investors with substantial shareholdings (of $10 \%$ or more)

\section{German REITS}

REITs did not start early in Germany for lack of enabling legislation as in many parts of Europe (www.reits.com). The law setting up German REITs (G-REITs) was enacted 1 June, 2007, and made retroactive to 1 January, 2007. The introduction, as in UK, was sequel to the fear of losing investment capital to other countries. Nonetheless, there still was political resistance to these plans, especially by the Social Democratic Party ('SPD'). (www.edinformatics.com/investor_educati on/reits.htm). The legal details seem to adopt much of UK-REITs regulations (taxation, public listing, etc.). According to Hughes (2005), an analysis prepared by Germany's Centre for European Economic Research (ZEW) and the European 
Business School (EBS) estimated that $\$ 140$ billion of corporate and $\$ 130$ billion of unleveraged residential real estate could be spun off into REITs.

\section{REITs in Canada}

The Limited Partnerships as well as open-ended and close-ended mutual funds were thriving in Canada by the time REITs were already booming in US. The first Canadian REIT was listed on the Toronto Stock Exchange in 1993 (Deloitte, 2004). Subsequently, many REIT companies have been listed just as some mergers have taken place. In Canada, investors allowed REITs to operate more like traditional real estate companies by a process of local adaptation in which many of the imposed restrictions were loosened. The Canadian REITs market was considered matured and developed so much that unit holders show willingness to accept variations from the 'rigid standards' established at the beginning of its operations (Deloitte, 2004). The strict disclosure rule is adopted in Canada. They are required to disclose in their financial statements, the net income per unit of investments.

REITs are also known to have been embraced, though at various levels and dimensions, in many other societies of the world economy including Hong Kong, India, Japan, Malaysia, Singapore, South Korea, and Taiwan. In many instances, however, the institutionalisation of REITs sprang as a response to the control of home real estate market by foreign concerns especially the US. Similarly certain more liberal regulations quite at variance with the original 'strict' US benchmark were specified.

\section{Benefits of REITs}

In general, the advantages inherent in the operations of REITs can be summarised as including the following:-
The tax shelter it offers: No corporate taxes are expected to be paid as long as up to $95 \%$ of profits are distributed as dividend to investors. Taxation occurs only at shareholder level in the form of income tax. This translates to having more profits to distribute to shareholders. Each dividend distribution (per share) is referred to as Property Income Distribution (PID) (www.telegraph.co.uk/money).

Portfolio diversification

REIT shareholders have ownership at least in part, in a portfolio of Real Estate equities. Whereas an investor in Real estate syndicate has his fund put on one property or the other, the REIT investor has his (however small), spread over many properties which may include office buildings, apartments, shopping centres, and industrial facilities.

Liquidity in real estate

While a regular investor in Real Estate cannot sell part of his holding, REIT's shares are tradeable in major exchanges making room for part-ownerships and instant liquidity of investment

Professional management

REITs enjoy professional management. The management combines professional real estate skills with financial and business expertise. The investors therefore do not need to posses specialist knowledge in its operations to enjoy an opportunity for high level investment performance.

\section{Applicability in Nigeria}

Researchers including Nubi (2007) attested to the state of housing finance in Nigeria as distraught. Even the provisions of the National Housing Fund (1992) for the funding of the mortgage system were scuttled partly by administrative bottlenecks and logistics. Sanusi (2003) cited that while fund mobilisation as at September 2000 was in the order of N5.8 billion from about 1.8 million contributors, 
a meagre sum of N375 million, was disbursed to 631 contributors through 20 Primary Mortgage Institutions because of the bureaucracy of documentation and the likes.

REIT could possibly complement the available provisions for real estate finance. Even then, the sectors with seemingly idle pools of fund (insurance and pension funds inclusive) are not empowered to 'overinvest' in real estate for many reasons including the sensitivity of their funds and the cautions not unrelated to sector risks. While Pension Funds, for instance are not empowered to engage in Corporate Debt Securities (including, but not limited to REITs \& Mortgage Backed Securities) beyond $30 \%$ mark, their current assets structure shows an investment of about \#469 million representing $0.48 \%$ (measured against the recommended 30\%) in this sector (PenCom, 2008). This source however, projected that given a growth rate of $20 \%$, Pension Funds are capable of providing a significant portion of the required mortgage financing required by 2020.

The non-banking sub-sector of the formal housing finance market in Nigeria comprises a wide range of security-market arrangements including the Security and Exchange Commission; The Stock Exchange; and the Discount Houses. The REITs phenomenon, being a security issue, depends on the proper functioning of this sub-sector among other things.

\section{Some Germane Considerations}

In consideration of policy implications of structural options in the bedevilment of REITs in Europe, Campbell and Sirmans (2002) examined certain issues. Some of these, which are also relevant in the institutionalisation of REITs or REIT-like vehicles in Nigeria include:

Restriction on concentration of ownership
What should be the guidelines for determination of minimum membership number? If REITs are created with the purpose of spreading participation, small groups of economically or politically powerful people should be precluded from wholly owning REIT organisations. The US situation prescribed a membership of not less than 100, the largest five of which must not control as much as $50 \%$ of holdings. This is commonly called the "550 " rule thereby effectively limiting the average maximum participation of any REIT investor to about $9 \%$ or less. Bearing in mind the Nigerian situation in which most sectors of the polity had suffered varying grades of highjack by a few persons, should this "5-50" rule be considered okay, expanded or tightened?

The case of institutional investors

Should institutional investors (e.g. pension funds, mutual funds organisations, etc) be subjected also to this "5-50" rule or be allowed to hold large stakes? It would be recalled that REITs are essential vehicles designed primarily to allow small investors to co-own investments in diversified real estate portfolios rather than the already large institutions which ordinarily can invest directly in real estate. The percentage of earnings required to be paid out

The US REIT arrangement required payment of at least $90 \%$ of earnings as dividend. However, it has been found that they paid well over $100 \%$, the excess resulting from difference between real and book value of investments as earlier explained. REITs in The Netherlands and Belgium were required to pay $95 \%$ and $80 \%$ respectively. Bearing in mind the Nigerian socio-economic environment, what percentage payment would be appropriate and what criteria would dictate this? 
The issue of leverage: There exists a possibility that REITs may carry large quantities of debt in the bid to achieve growth in earnings especially during times of expansion. However, Campbell et al. (2001) claimed that this can result in early liquidation. Evidences, they claimed, abound to support that over leverage may be an important factor causing REIT mergers or REIT liquidation. Bearing in mind the collapse of Nigerian primary mortgage institutions in the 1990s and the extent of leverage involved in operations then, what margin of leverage is likely to be allowed in Nigerian REITs market? In Belgium, claimed Fickes (2001), a ceiling of $50 \%$ debt-to-assets ratio was allowed.

Information disclosure order: The need is strong for transparency in this regard. In Nigeria where the implementation of the 'Freedom of Information' law obtains mainly in theory, what special disclosure requirements would be necessary to ensure that the REITs system is not abused?

The Nigerian Stock Market Situation: Notwithstanding the several rebuttals of the effect of the world global meltdown on the Nigeria sub-market, prices of stock had been noticed as dwindling since early August 2008 before the big crash which followed. The Nigerian stock market had, however, been plagued with series of problems. The case of inappropriate pricing, price fixing and share manipulation had been witnessed in Nigerian stock trading on shares of oil and gas companies, banks and so on. Problems of round-tripping too had been monumental just as private placement and public offers suffer delays in issuance of Certificates and money returned cases (Odunlami and Mukwuzi, 2008).

These and other peculiarities of the Stock Exchange were compounded by the controversy regarding margin trading. This entails the operations of some brokers, fund managers and hedge fund operators taking bank loans to buy shares for resale to make quick profits (Okiti, 2009). The market swings at the Nigerian Stock Exchange for some randomly selected companies on particular dates (as depicting investors' reactions) can be captured in the Table 1 below. It shows the plunge in the stock market even before the official entry of the global meltdown and the situation thereafter. It further traces the development to 2009 and compares these with the current (2016) situation. 
Table 1: Trends in Nigerian Stock Market

\begin{tabular}{|c|c|c|c|c|c|}
\hline Some selected companies & $\begin{array}{l}\text { Share as } \\
\text { at Dec. } \\
7,2007\end{array}$ & $\begin{array}{l}\text { Share as } \\
\text { at Aug. } \\
19,2008\end{array}$ & $\begin{array}{l}\text { Share as } \\
\text { at April } \\
17,2009\end{array}$ & $\begin{array}{l}\text { Share as } \\
\text { at July } 1 \text {, } \\
2013\end{array}$ & $\begin{array}{l}\text { Share } \\
\text { prices as } \\
\text { at March } \\
30,2016\end{array}$ \\
\hline
\end{tabular}

\section{(i) Agriculture}

Livestock feeds plc

Okitipupa Oil Palm plc

$\begin{array}{lllll}3.24 & 3.80 & 1.10 & 5.11 & 1.12 \\ 2.35 & 7.35 & 6.53 & \text { NA } & \text { NA }\end{array}$

(ii) Banking

Diamond Bank

Skye bank plc

$\begin{array}{lllll}16.98 & 12.00 & 4.38 & 6.10 & 1.30 \\ 29.50 & 19.63 & 6.00 & 4.70 & 0.99\end{array}$

(iii) Building materials

Ashakacem plc

Benue Cement plc

50.50

29.95

8.50

NA

24.00

(iv) Conglomerates

A.G.Leventis Nig plc.

UAC N plc.

49.15

46.00

21.00

NA

NA

(v) Mortgages

$\begin{array}{lllll}4.46 & 9.88 & 6.79 & 1.53 & \text { NA } \\ 45.02 & 40.00 & 30.50 & 54.12 & 20.48\end{array}$

Union Homes Savings \&

6.90

5.51

1.54

NA

4.50

Loans

2.21

0.90

0.50

NA

(vi) Real Estate

UACN Property Devt.

$20.95 \quad 25.18$

18.16

14.81

4.61

(vii) REITs

Skye Shelter Fund plc

$116.85 \quad 105.46$

NA

UPDC REIT

$\begin{array}{rrrrl} & 116.85 & 105.46 & & \text { NA } \\ 51.50 & & & 10.00 & \text { NA } \\ & & & & 45.22\end{array}$

Source: Compiled from Business Day Vol 6, No 246 (December 10 2007), Vol. 7 No. 423 (August 20, 2008), Vol. 7 No 596 (April 20, 2009), Vol. 11, No 129 (July 1, 2013), Vol. 14 No 64 (May 30, 2016). www.businessday online.com. NA stands for Not Available

The figures quoted above are in Nigerian Naira. Generally, with the exception of some companies at the conglomerates and agriculture groups, stock prices which plummeted about midAugust 2008 had further fallen by April 2009. Variegated improvement and depressions were recorded in 2013 just as the figures fell further in 2016. Generally, this shows quite a long stretch of capital and income loss with heavy casualties recorded within the Nigerian economy.
This scenario does not present an encouraging pedestal for thriving stockoriented investments like REITs for now.

\section{Conclusion and Recommendations}

Finance is the nub of housing delivery. Both the traditional and modern modes of housing finance in Nigeria are prone to the respective sector inadequacies. The inadequacies of the current domestic methods of housing financing, which highlights the extent of housing poverty in 
Nigeria, deserve a paradigm shift especially in the direction of REIT. However, while there are various types of REITs as well as structures thereof, efforts at learning by Nigeria from the other lands in a globalising world, should take the local peculiarities into consideration. It is not advisable that the foreign structure REITs be imported wholesale; rather a home-grown REIT or Nigerian adaptation would be preferable for success to be achieved without having to relive the nightmare in the form of the erstwhile massive collapse of mortgage institutions in Nigeria.

As the REIT market is new in Nigeria, the level of its awareness too is low. A REIT education and regulatory institution is therefore desirable in Nigeria. This would address the framework necessary for its operations, the accompanying tax provisions/reforms as well as the several other posers raised in this study. The ownership structure, for instance, deserves a clarification especially along the "5-50" rule to forestall highjack by powerful families. Additionally, the operations of REITs have to be specifically defined and supervised to steer them clear of shortcuts (like commodity trading and related activities), which ruined the mortgage arrangements in the 1990s.

Meanwhile, some questions arise in REIT considerations in Nigeria. For instance, is the focus of REIT specifically on boosting housing delivery or enhancing investors' return? Furthermore, does it really release much money into housing delivery in the face of its provision for little plough-backs? An attempt to plough back substantial portion of the profit may result in low dividends. The misinterpretation of this as a fall in earnings or/and cash flow can send out distress signals. The need to broaden the investment profile may also lead to lowered profitability which could result in panic from investors comparing earnings therefrom with similar investments.

The requisite infrastructures needed for REIT to survive have to be put in place and nurtured in Nigeria. The stock exchange, in this respect, deserves shoring up, and injection of transparency. Similarly, specific structural adjustments are required to prevent fraud and corruption (especially as REITs do not pay corporate tax) in the pursuit of transparency and strict disclosure.

\section{Reference}

Amao, F.L. and Odunjo, O.O. (2014). Housing Finance in Nigeria. Journal of Economics and Sustainable Development, 5(27): 101-104.

Campbell, R.D., Ghosh, C. and Sirmans, C.F. (2001). The information content of method of payment in mergers: evidence from real estate investment trusts (REITs). Real Estate economics, 29(3): 361-387.

Campbell, R. and Sirmans, C. (2002). "Policy implications of structural options in the development of Real Estate Investment Trusts in Europe: lessons from the American experience", Journal of Property Investment \& Finance, 20(4): 388405.

Delloitte (2004). REIT guide ( $8^{\text {th }}$ edition, Second Print). Toronto: Deloitte \& Touche

LLP (www.deloitte.com/dtt/.../0,1015,cid \%253D9343,00.html) accessed July 14, 2009

Fickes, M. (2001). "A Continental Flair" Real Estate Portfolio JanuaryFebruary 44-46

Hamson, L. (2001). 'Cruel Britannia', Property Week, April 7 
Hughes, F. (2005). The Long Road to PanEuropean REIT. Real Estate Portfolio (Special edition) Nov/ Dec

Kama, U., Yakubu, J., Bewaji, P., Adigun, M. A. A. and Olubukola E. J. D. (2013) Mortgage financing in Nigeria. CBN Occassional Paper No 50. Abuja: $\mathrm{CBN}$

Mabogunle, A.L. (2004) An African Perspective. In a future for Urba Planning? UN-HABITAT Debate 10 (4), 12.

Nathanson, (2006). How to become a UK -REIT (www.nabarro.com) accessed June 26, 2008.

Newell, G. and Fife, A. (1995). Major property investor attitudes to property securitisation. Journal of Property Finance, 6(2): 8-19.

Nubi, T.O. (2007). Secondary Mortgage Market in Nigeria: the Old is Dead; is the New Ready to be Born? Private Sector Driven Housing Delivery: Issues, Challenges and Prospects, (Nubi, T.O., Omirin, M.M. and Afolayan, A.S. (eds.)) Lagos: Department of Estate Management, University of Lagos, pp. 196-221

Odunlami, T. and Mukwuzi, M. (2008). Teeth gnashing on the bourse. The News, 13(08) September

Okiti, O. (2009). Nigerian 'shenanegan' exchange. Business Day, vol. 7 No 596 (April 20)

PenCom (National Pension Commission) (2008). Pension Funds as a Catalyst for Sustainnable Secondary Mortgage Market Finance System for Nigeria. Presentation at $5^{\text {th }}$ LBS/ Pan African University Conference on Real Estate. (October)

Sanusi, J.O. (2003). Mortgage Financing in Nigeria: Issues and Challenges. Paper presented at $9^{\text {th }}$ J. W. Ekpeyong Memorial Lecture of the Nigerian Institution of Estate Surveyors and Valuers (Jan. 29).

Walmsley, A. (2007). Pension Funds and Housing Finance in Nigeria. Paper presented at a 3-day International conference on housing finance in Nigeria organised by Foundation for Development Initiatives (FDI) between 17 and $19^{\text {th }}$ October

World Bank (2008) World Bank Report. (www.edinformatics.com/investor_educati on/reits.htm) accessed July 15, 2009.

(www.financeasia.com) accessed July 15. 2009.

(www.housingfinanceafrica.org) Accessed on $25^{\text {th }}$ April 2012

(www.kpmg.co.uk/industries/cm) Accessed $23^{\text {rd }}$ April, 2008

(www.InvestinREITS.com) Accessed on September 29, 2006

(www.overseaspropertymall.com accesse $17^{\text {th }}$ August 2010

(www.reits.com) accessed $12^{\text {th }}$ Dec 2008

www.telegraph.co.uk/money accessed on 23/04/08 